\title{
Discussions about the Best Methods of Collision between Merchant Ships and Fishing Boats during Fishing Seasons Near Chinese Coast
}

\author{
X.K. Wang, Z.X. Zhou, Y. Liu, X.K. Wang, H.R. Song \\ Marine college of Shandong jiaotong university \\ Weihai, China
}

\begin{abstract}
With our country's economic developments and the developments of fishery, near the coast of China, the number of fishing boats and merchant ships are becoming biger and biger. Sometimes, the collisions between fishing boats and merchant ships have occurred. While most of the collisions happened during the fishing seasons, therefore, it is necessary to study the best methods to avoid the collisions between the chinese coastal merchant ships and fishing boats, in order to avoid the collisions between Chinese coastal fishing boats and merchant ships.
\end{abstract}

Keywords-fishing boat; fishing season; avoid; the best methods to avoid the collisions

\section{INTRODUCTION}

As a shipping country and fishing power, China has a $18000 \mathrm{~km}$ stretch of coastline of mainland. Fishing boats and merchant ships are also frequently intersection near the coastal waters, the collisions of merchant ships and fishing boats have sometimes occurred. And each of the collision accidents often caused the fishing boats crashed and casualty. So in order to ensure the safety of navigation, protect the marine environments and decrease people's lives and property loss, we should to try to avoid the occurrences of the collision accidents between merchant ships and fishing boats, but avoid the intersection between merchant ships and fishing boats, will effectively avoid collisions between merchant ships and fishing boats. Therefore, based on the research and analysis of the basic characteristics of the coastal fishing boats' collision, discuss the question how we can carry out the route designed before merchant ships start navigation in China coastal waters. If we navigate along the designed route, we can effectively avoid the collisions between merchant ships and fishing boats.

\section{THE ChARACTERISTICS OF CHINESE COASTAL FISHING BOATS' COLLISIONS[4]}

\section{A. Seasonality}

My country is rich in fishery resources, which has a long coastline, many excellent fishing grounds in her coastal waters. However, in recent years, because the fishermen's abuse of fishery, the sharp contraction is caused by fishery resources in the coastal areas of China, for the protection of fishery resources, the provision was made by the relevant departments of the state, in the Yellow Sea and the East China Sea, more than latitude 35 degrees north of the area from June 16th 1200LT to September 1st 1200LT for the fishing moratorium; Latitude 35 degrees north to latitude 26 degrees 30 minutes north from June 16th 1200LT to September 16th 1200LT for the fishing moratorium; latitude 26 degrees 30 minutes north to the south part of the east China sea, More than latitude 12 degrees north of the South China Sea (including the Beibu Gulf), latitude 22 degrees 30 minutes north to latitude 23 degrees 30 minutes north, longitude 117 degrees east to longitude 120 degrees east of the experience of fujian-guangdong boundary waters from June 1st, 1200LT till August 1st,1200LT for fishing moratorium. During the moratorium period, fishing boats are banned fishing, and fishing boats generally won't go out to sea to do fishing operations during the period of the moratorium. so during the moratorium period, there be rarely encounter between merchant ships and fishing boats, few collision accidents between merchant ships and fishing boats, while in the non moratorium, especially during the annual 3-5 months and 10-12 months, the fishing seasons, all fishing boats try very hard to fishing, tens of thousands of fishing boats will be gathered in the sea area, thus the collision are caused frequently, and the frequency has been showed a rising trend year by year. [5]

\section{B. Time Period Concentrated}

From the statistics of merchant ships and fishing boats of collision accident, we can clear draw a conclusion that most of the collision accident happened in the night, the night collision accidents is about more than $70 \%$ of the accidents, most of the collision accidents happened during 0000LT to 0400LT in the morning, more than $50 \%$ of the accidents happened in this period. . The reasons for this situation, mainly related to the crew fatigue and tension. Some fishing boats only focus on the benefits, , regardless of days and nights, pay close attention to the production all the time, and often have lower labor intensity of the sailing time as the rest time. What's more, some fishing boats in order to reduce costs, without authorization in violation of regulations of reducing the crew manning, increasing the labor intensity of the crew, the pursuit of profit maximization practice, which makes the fishing boats crew can not get a very good rest, resulting in the personnel on duty unresponsive, decreasing of alertness, even fell asleep on duty, and merchant ships' drivers are the most sleepy during 0000LT to 0400LT in the morning, and the captain is aslo resting at this time, some duty officers think captain without supervision, and lax stage in the thoughts, in this way, because the fishing boats and 
marchent ships' two aspects of reasons, the danger of collision becomes bigger.

\section{Happens Easily when Visibility is Poor[9]}

For the coastal waters of China are fog area, because of the fog, visibility is poor, visibility has had a huge impact on the ships' sailing, anchoring, safety production. Due to the influence of visibility, the risk of collision increases greatly. At the same time, because the fishing boats operating way, equipment configuration, the quality of personnel and other reasons, also increased the proportion of the fishing vessel accidents in restricted visibility, such as a fishing boat was hit sink which has not been equipped with radar, which was in the waters of the stadia is only 50 meters without displaying the light signals or sounding the fog signals ,sailing adventures omely, in violation of the rules, inevitably bringing serious consequences. And merchant ships' seamen sometimes rely too much on radar observations, thinking no ship echoes on the radar screen, there is no ship existing, little imagine, limitations of the radar,

because of the scale of the fishing boats are small, with weak radar waves reflection ability, it is difficult to observe, in the wind and waves, because of the effect of wind wave echoes, more of the sea wave echoes appear on the radar screen, fishing echoes submerged in the numerous echoes on the radar screen, more difficult to recognize, such as when fishing boats approach near and are identified as the ships, it is too late. .And some fishing boat crew also think merchant ships will take the initiative actions to avoid fishing boats, the fishing boats don't arrange for the personnel on duty when they are in fishing, or they arrange for the personnel on duty, but the duty crew focus on fish searching, rather than on the outlook on duty; What's more, some fishing boat crew under the psychological self in sustaining fishing boats smaller, flexible manipulation, coupled with a "grab too big bow, three years to eat and drink not sorrow" psychological, seeing the merchant ships they do not give a way for merchant ships, instead of going through the bows of the merchant ships. And some fishing boats are not equipped with communication equipments, or are equipped with, but with the communication equipments standing by on the agreed channel between fishing boats, not on public channel, merchant ships and fishing boats' coordination communication call is impassable, although some unattended in public channel, but because of the use of the language of the fishing boats' crew difference from merchant ship seamen, they can't communicate effectively, which constitutes the important hidden trouble of safe navigation, increases the possibility of collision. According to statistics, of all the collisions of merchant ships and fishing boats, up to more than $67 \%$ of the accidents are caused by poor visibility.

\section{The Waters Concentrated}

Collision accident mainly occurred in the sea areas such as the Bohai Strait, the Yangtze estuary fishing grounds, Zhoushan fishing ground, the Taiwan Strait, etc. dense waters of merchant ships. [10]

\section{E. Significant Accidents or more than Serious Accidents is Many, Casualties Is Serious}

According to statistics, from 2006 to 2010, fishing boats and ships collision number is $19.18 \%$ of fishery safety accidents, but deaths (missing) accounted for $48.52 \%$ of the total. Sunken ships and death (missing) 3 or more of the larger accident has 26, resulting in death (missing) personnel 145 people, on average every accident death (missing) for more than five people. In 2011, the fishing boat collision accidents account for $9.3 \%$ of the fishing vessel accident, and the death toll is as high as $29.3 \%$ (missing).Merchant vessels and fishing vessel collision accident death rate is far higher than other types of accidents (missing).Collision accident, once the boat was struck sunken ships will be a large number of casualties of fishing boats crew . [11]

\section{The PRESENT Status of Vessel INTERSECTION IN THE COASTAL W ATERS OF CHINA}

There are several very complex waters of navigation environment along the coast of China: [6] (1) The Laotieshan channel and the Changshan channel are important channels of the Bohai sea, the channels for merchant ships sailing are very narrow, ships navigate in or out of the ports of the Bohai Bay from different directions to gather and spread out, traffic density is quite large, and many ships' course are crossing, besides many vessels underway are in the channels, a large number of fishing boats are outside the channels. The navigation environment is more complex, ship collision accidents happened frequently in this area. (2) The Chengshantou is the maritime transport hub in China, because which has traffic flow to Laotieshan channel direction, Changshan channel direction, Dalian direction, the direction of Japan and South Korea, north and south direction, traffic density is big, fishing vessels gathered here because it's rich in fishery resources. Which is also a high incidence of crashes in coastal waters. Some ships do not actively cooperate with Chengshantou traffic center, the relevant provisions on traffic separation scheme are not followed strictly, this may increased collision accidents in the waters, too.(3)The broad waters of the Yangtze River Estuary includes west of longitude 123 degrees east, latitude 29 degrees north to latitude 31 degrees north.

Traffic density is large in the area. A large number of ships are north-south route transit ships, in and out of Shanghai ports, ports of the Yangtze river, zhoushan islands, ports of Japan and South Korea. This area is a famous fishing grounds. There were various kinds of fishing ship. But outside the north-south route of the mouth of the Yangtze River did not establish a traffic separation scheme, every ship in their customary route running, no order, heading crossing multiple, for ship collision avoidance has left a hidden safety trouble. And with the increasing of coastal traffic, many merchants usually take line 123 degrees east longitude as planned route, in this route it will meet shiping ships, and the greater influence of otating flow is high, leading to ship must use large flow pressure difference to maintain the tracks that made this area has a high probability of collision.(4)The Strait of Taiwan has more than 200 nautical miles, there are only $60 \mathrm{~nm}$ in narrowest point, no traffic separation scheme 
setting, and this area is the collision accident prone area, accidents are mainly concentrated in the Xiamen and Dongshan Island, Niu Shan Island East of the sea(5)The Pearl River estuary is a port intensive areas in South China, the region of the traffic density is large, the collision accident rate is very high.

\section{The OBJECTIVE COLLISION REASON OF Fishing BOATS AND MERCHANT SHIPS}

There are a number of Collision reasons for Chinese coastal ships and shiping boats, but a large number of intersection of fishing boats and merchant ships are the main eason[7]. Because of the China coastal area ship navigation density, ship sailing in coastal waters were already amounted to about 4600000,is expected 5000000 by 2015 will reach about. And in fishing season, there are nearly one million of fishing boats operating in chinese coastal at the same time .then, in the fishing has not magnificent city night landscape. But the perplexing coastal route, Dense, fishing areas, coastal habits route of merchant ships crpssing with fishing boat that import and port of port, For example from Shidao to Chengshantou. Moreover, the work area of fishing area and customary route was connected together, and the driver usually thought they have higher ship operating level, in order not to deviate from the planned route, generally, to a lesser extent avoidance, such as when avoid a fishing boats, DCPA value rarely taken more than 0.5 sea miles, Some of them use DCPA value was only 0.2 sea miles and some take even smaller, at the time of avoidance to the boat, the habit often thought was far away from the situation that considered, and delay the best time to take action, lead to uncoordinated avoidance actions easily, failed to strictly comply with the rules specified in "early, big, wide, clear," the avoidance principle. Some ship driver sailing into the intensive area with a high speed, and in these waters, Usually the fishing boats often use their operation habit ,In many cases, Fishing traffic flow and merchant traffic flow was crossing, and the fishing vessels did not comply with traffic rules regulations, only pursuit of high efficiency, forced through the bow of a merchant ship, what is more, fishing boat often thought that the merchant will avoid boats, it increased the possibility of collision between fishing boat and merchant vessel.

\section{COLLISION PRINCIPLE AND METHOD BETWEEN MERCHANT VESSELS AND FISHING BOATS IN CHINA COASTAL SAILING}

\section{A. The Best Way to Solve China Coastal Sailing between Merchant Vessels and Fishing Boats Collision}

When sailing in coast, ship encounter fishing boat more often than other situation, large vessel often have big inertia and the empty boat have big blind area, generally above 200 meters, Semi-flow coefficient is big and Redirection capability is poor, the rudder effect is not good when use small rudder angle, if within $5 \mathrm{deg}$, the rudder has little effect. come after, because the ship's inertial, rudder effect is not good, it is difficult to get the course; ice voyage due to wake the existence of steerage disappear soon, almost half minutes without rudder. Therefore, in the fishing season, [8] the best way is to hang around for large merchants if encounter large fishing vessels, so the design of routes, should according to the fishing area fishing season as much as possible to avoid the fishing zone. While in some cases, had to cross the fishing group, the CCW must keep a proper lookout, a safe speed, If necessary increase on duty, Due to large ship manoeuvring characteristics, when use rudder must early, with large rudder angle. But the reality is, when fishing boats sailing in groups, sometimes because of ship swing waters is limited, it is difficult to do early let the lenient, as in the fishing season, because fish area may extends for tens of miles, and the distance between the fishing is also very small, sometimes want to find a 1 miles above the empty block are very difficult, so, in the fishing season, the best is still very good planning route to through fishing area is avoid the fishing area.

\section{B. Optimization Principle Collision Avoidance in China Coastal Navigation}

In China coastal navigation, in order to need avoid fishing vessels safely, When design a new route if in a traffic lane waters should be according to the traffic lane navigation; If there is no traffic lane waters the $\mathrm{CCW}$ should according to the habit of the ordinary practice; if allowed, the route should not too close to the shore line. Such as the LaoTieShan, Chengshan area, the Qiongzhou Strait, Zhujiangkou waters should be according to the traffic lane navigation. For there is no traffic lanes and used to route water, need to the fisheries sector and the maritime departments timely release information notices fishing season as the content, the need to understand the details of the crew fishing information, and the distribution range of the fishing area marked on the chart, design route should avoid fishing area.

\section{The Reason for China's Coastal Navigation Choice in Traffic Lane And Habits Sailing on the Main Route[1]}

Because that most of the fishermen know the distribution of the position and the provisions of the ban on fishing in waters off traffic lane traffic lane, fishing is also very dangerous in the traffic lane, fishing waters and outside traffic lane. There is little or no merchant vessels pass are safe and fishing waters, so the fishing boats are generally engaged in fishing waters of the outside traffic lane, especially in fishing season, outside the channel to the surface of the lights, the merchant if not in traffic lane navigation, its dangerous degree. [3]

And the habit of sea route, one is the right distance away from the shore, enough water depth. And the distance also won't have too much; Second, the fishermen, usually a few fishing boats in engaged in fishing waters used the main route, so the main route navigation by habit, greatly reduces the chance of encounter with engaged in fishing boat. Caofeidian port, back and forth as the north-south route ship should transit through the old iron mountain, and should not in order to shorten their teens and $20 \mathrm{~nm}$ range and endurance of the temple of the island's waterway, so as to avoid accidents and fishing boats, YangShiChuan, breeding facilities or trouble; Appropriate sail away from the shore, but also can avoid or reduce encounter with fishing boats, all kinds of fishing in coastal waters are often much more 
special, but far away from the shore of $123^{\circ}$ line fishing boat was significantly reduced, so the design route should stay away from the shore appropriately, avoid the fishing boats would greatly increase the safety coefficient.

\section{The Specific Implementation of Avoiding in China Coastal Navigation}

Comprehensive China coastal route guide and customary route, The main principle is safety and economy .Highlight the recommend collision avoidance route from Chinese northern port to China southern port for navigation colleagues discuss. Because of the author's ship work mainly for large ships, so large ships as an example:

\section{RECOMMENDED COLLISION AVOIDANCE METHORD FROM BOHAI COAST TO THE GUANGDONG[2]}

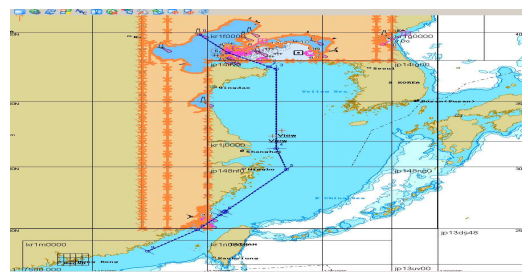

FIGURE I. RECOMMENDED COLLISION AVOIDANCE METHORD FROM BOHAI COAST TO THE GUANGDONG

From the shore of Bohai port to Qinhuangdao, should selection WPT1 $\left(39^{\circ} 50^{\prime} .8 \mathrm{~N}, 119^{\circ} 38^{\prime} .8 \mathrm{E}\right)$ Driving course $143^{\circ}$ to WPT2 $\left(38^{\circ} 34^{\prime} .6 \mathrm{~N}, 120^{\circ} 54^{\prime} .0 \mathrm{E}\right)$, That is, after Laotieshan waterway Nishiguchi, change driving course $126^{\circ}$ out of waterways to Laotieshan WPT3 $\left(37^{\circ} 33^{\prime} .7 \mathrm{~N}\right.$, $\left.122^{\circ} 40^{\prime} .2 \mathrm{E}\right)$, change course $150^{\circ}$ to WPT4 $\left(37^{\circ} 23^{\prime} .65 \mathrm{~N}\right.$, $\left.123^{\circ} 00^{\prime} .0 \mathrm{E}\right)$, change course $180^{\circ}$ to WPT5 $\left(31^{\circ} 26^{\prime} .0 \mathrm{~N}\right.$, $\left.123^{\circ} 00^{\prime} .0 \mathrm{E}\right)$, change course $154^{\circ}$ toWPT6 $\left(29^{\circ} 47^{\prime} .6 \mathrm{~N}\right.$, $\left.123^{\circ} 25^{\prime} .8 \mathrm{E}\right)$, change course $215^{\circ}$ toWPT7 $\left(26^{\circ} 23^{\prime} .0 \mathrm{~N}\right.$, $\left.120^{\circ} 44^{\prime} .0 \mathrm{E}\right)$, change course $213^{\circ}$ to WPT8 $\left(25^{\circ} 23^{\prime} .0 \mathrm{~N}\right.$, $\left.120^{\circ} 00^{\prime} .0 \mathrm{E}\right)$, change course $220^{\circ}$ to WPT9 $\left(24^{\circ} 54^{\prime} .0 \mathrm{~N}\right.$, $\left.119^{\circ} 33^{\prime} .0 \mathrm{E}\right)$, change course $228^{\circ}$ to WPT10 $\left(23^{\circ} 08^{\prime} .0 \mathrm{~N}\right.$, $\left.117^{\circ} 25^{\prime} .0 \mathrm{E}\right)$, From this point can be to Guangdong coastal port.

\section{ADVANTAGE OF THE GIVEN RECOMMENDED RouTE}

\section{Advantages:}

Most of the route depth waters exceed 30 meters, the route is close to Chinese mainland and the islands, could use landmarks and radar positioning; Moreover, due to sufficient depth, the ship suffered minor resistance, speed, little affected, effectively saving.

(2)Due to water depth, better ship handling performance, high avoidance capability, while relatively small fishing boats in the vicinity of routes, can well reduce collisions with fishing vessels, Meanwhile, Ship aground accidents can be avoided.

(3) Because of the influence of winter wind, on the whole route of most waters, ships or partial downwind sailing (south),or partial wind sailing (northward),to avoid cross-wind sailing conditions conducive to manipulate the ship to ensure the navigation safety.
(4) The route is shorter than the recommended route, although little savings range during a single voyage, but for frequent coastal ships sailing in China, the total annual amount of savings is very large.

\section{VIIICONCLUSION}

If each of China's coastal sailing ship, have paid attention to the design routes, and consider security and economic aspects, then will greatly improve China's coastal sailing order and navigable environment. This is to reduce collisions merchant and fishing vessels, and these will greatly protect people's life and property safety, reduce the risk of pollution from ships, improving the efficiency of maritime traffic, and promote economic development of shipping. So, China's marine transportation and marine fisheries production will produce a greater historic step.

\section{REFERENCES}

[2] Xionghua Wang. Explore the Taiwan Strait routes[C].Maritime Exchange and The Taiwan Strait Academic Symposium Navigational Safety Prevention.1988.12.

[3] Qiliang Fu. Route Reflection of the Route designe of the coastal waters [J].Navigation Technology.2012.3

[4] Jinchao Wu, Jincai Chen. Talk about the Design of The Navigation Route[J].World Maritime.1996.3.

[5] Jingguo Ding. Research on the Issue of Maritime Security Avoidance of Merchant ships and fishing boats [J].China Navigation.2003.3.

[6] Feng Liu. Research merchant and fishing vessels to prevent collisions[J].Navigation Technology.2010.5.

[7] Libiao Deng. Analysis and Countermeasures of Merchant ships and fishing vessels collide Accident[C].Proceedings of the marine ship collision avoidance.2005.8.

[8] Yongqing Ji.To investigate the Accident Prevention Merchant and Fishing Vessels Collide[J].Avoidance and safe operation of the ship.2007.4.

[9] Libiao Deng. Analysis and countermeasures of collision of Merchant and fishing boat fishing[J].Avoidance and safe operation of the ship2007.4.

[10] Wei Wang.China Analysis of Merchant avoid coastal fishing[J]..Nantong Vocational and Technical College.2010.12.

[11] Jian Yu. Qiumei Chen. Gang Zhang. Merchant ships and fishing boats collision analysis and preventive measures[J].Qingdao Ocean Shipping Mariners College .2007.1.

[12] Qianyun Li, Shengcun Zeng. Research on collision Merchant ships and fishing boats[J].Chinese Fisheries Economics.2012.2. 